\title{
Losing cichlid fish biodiversity: genetic and morphological homogenization of tilapia following colonization by introduced species
}

\author{
Asilatu Shechonge $\mathrm{A}^{1,2,3} \cdot$ Benjamin P. Ngatunga ${ }^{1} \cdot$ Rashid Tamatamah $^{1,2}$. Stephanie J. Bradbeer ${ }^{3}$. Jack Harrington ${ }^{3}$. \\ Antonia G. P. Ford ${ }^{4}$. George F. Turner ${ }^{5} \cdot$ Martin J. Genner $^{3}$ (])
}

Received: 22 December 2017 / Accepted: 9 July 2018 / Published online: 18 July 2018

(c) The Author(s) 2018

\begin{abstract}
Among the many negative impacts of invasive species, hybridization with indigenous species has increasingly become recognized as a major issue. However, relatively few studies have characterized the phenotypic outcomes of hybridization following biological invasions. Here we investigate the genetic and morphological consequences of stocking invasive tilapia species in two water bodies in central Tanzania. We sampled individuals from the Mindu Reservoir on the Ruvu river system, and at Kidatu on the Great Ruaha-Rufiji river system. We screened individuals at 16 microsatellite loci, and quantified morphology using geometric morphometrics and linear measurements. In both the Mindu and Kidatu systems, we identified evidence of hybridization between indigenous Wami tilapia (Oreochromis urolepis) and the introduced Nile tilapia (Oreochromis niloticus) or blue-spotted tilapia (Oreochromis leucostictus). At both sites, purebred individuals could largely be separated using geometric morphometric variables, with hybrids occupying a broad morphospace among the parental species. Our data demonstrate that the gene pools and phenotypic identity of the indigenous $O$. urolepis have been severely impacted by the stocking of the invasive species. Given the lack of evidence for clear commercial benefits from stocking invasive tilapia species in waters already populated by indigenous congenerics, we suggest further spread of introduced species should be undertaken with considerable caution.
\end{abstract}

Keywords Hybridization · Alien species · African freshwater fishes · Tilapia

Electronic supplementary material The online version of this article (https://doi.org/10.1007/s10592-018-1088-1) contains supplementary material, which is available to authorized users.

Martin J. Genner

m.genner@bristol.ac.uk

1 Department of Aquatic Sciences and Fisheries, University of Dar es Salaam, P.O. Box 35064, Dar es Salaam, Tanzania

2 Tanzania Fisheries Research Institute (TAFIRI), P.O. Box 9750, Dar es Salaam, Tanzania

3 School of Biological Sciences, University of Bristol, Life Sciences Building, 24 Tyndall Avenue, Bristol BS8 1TQ, UK

4 Department of Life Sciences, Whitelands College, University of Roehampton, Holybourne Avenue, London SW15 4JD, UK

5 School of Biological Sciences, Bangor University, Bangor, Gwynedd LL57 2UW, UK

\section{Introduction}

Hybridization is a widespread phenomenon in nature (Olden et al. 2004). In the field of invasion biology, hybridization is generally considered a negative process for biodiversity, as it can lead to the erosion of unique genetic diversity (Todesco et al. 2016). Hybrids may possess novel traits that enhance their potential to have deleterious impacts on indigenous populations (Gaskin and Schaal 2002; Facon et al. 2005). In freshwaters, genetic or demographic swamping during hybridization is now considered a major driver of biodiversity loss, alongside habitat loss and pollution (Scribner et al. 2000; Perry et al. 2002).

In Africa, freshwater ecosystems are critically important for both biodiversity and food security, supporting capture fisheries of major significance for inland human populations (Vörösmarty et al. 2010; McIntrye et al. 2016; Lynch et al. 2016; Winemiller et al. 2016). However, many major capture fisheries in Africa are overexploited, leaving little capacity 
for the successful expansion of existing fisheries through technological innovations or increased effort (Welcomme et al. 2010). The pressing need to increase fish production to meet the demand from a growing human population has led to initiatives to develop inland aquaculture across Africa. To date, such initiatives tend to have been based on a handful of species, among the most prominent being Nile tilapia (Oreochromis niloticus). The species has a natural distribution in the Nile system and west Africa, but is now successfully used in aquaculture throughout tropical and subtropical regions (Deines et al. 2016). However, following deliberate introductions or accidental escapes, Nile tilapia is now naturalized in water bodies in many of the 140 countries where it is cultivated (Deines et al. 2016).

Nile tilapia has been widely hybridized with other tilapia species in captivity to generate novel strains, many of them fertile (Eknath and Hulata 2009). There is also evidence of extensive hybridization of Nile tilapia with multiple indigenous Oreochromis species in the natural environment, including O. mossambicus in South Africa (D'Amoto et al. 2007), O. andersoni and O. macrochir in Zambia (Deines et al. 2014) and $O$. esculentus in Kenya (Angienda et al. 2011).

Tanzania is a hotspot for natural diversity of the genus Oreochromis. Here, Nile tilapia is native only to the Lake Tanganyika catchment (Trewavas 1983), but has been widely distributed across the country for aquaculture and fishery enhancement (Genner et al. 2013; Bradbeer et al. 2018; Shechonge et al. 2018). It was initially introduced into Lake Victoria in the 1950s (Goudswaard et al. 2002), where it is now the dominant species in the tilapia fishery with estimated landings of 36,000 tonnes per annum in 2011 (Mkumbo and Marshall 2015). At the same time, populations of the endemic Lake Victoria Oreochromis esculentus and $O$. variabilis have declined dramatically, perhaps through competitive exclusion and/or hybridization (Goudswaard et al. 2002). Most of the farmed and stocked Nile tilapia in Tanzania appears to have been sourced from Lake Victoria, which likely explains why it has been accompanied by blue-spotted tilapia (Oreochromis leucostictus), a relatively small-bodied species native to the Nile system of Uganda below the Murchison cataracts, which became established in Lake Victoria at the same time as $O$. niloticus (Goudswaard et al. 2002).

While sampling fishery catches in 2011-2012, we observed introduced Oreochromis in the Mindu Reservoir on the Wami river system (phenotypically $O$. niloticus and O. leucostictus) and at Kidatu on the Ruaha-Rufiji system (phenotypically $O$. niloticus only) (Fig. 1; Shechonge et al. 2018). In these areas, Oreochromis urolepis is the only indigenous Oreochromis species that has been recorded (Trewavas 1983; Eccles 1992). This large-bodied indigenous species continues to support major capture fisheries and represents a candidate species for future aquaculture, not least because of it tolerance of high salinity. In both the Mindu and Kidatu systems our field observations, based primarily on an apparent continuum of morphological traits and colouration of freshly landed individuals, suggested hybrids
Fig. 1 Sampling locations in Eastern Tanzania, including the focal sites (Mindu reservoir and Kidatu) and the sampling sites for reference material (Kerenge and Utete)

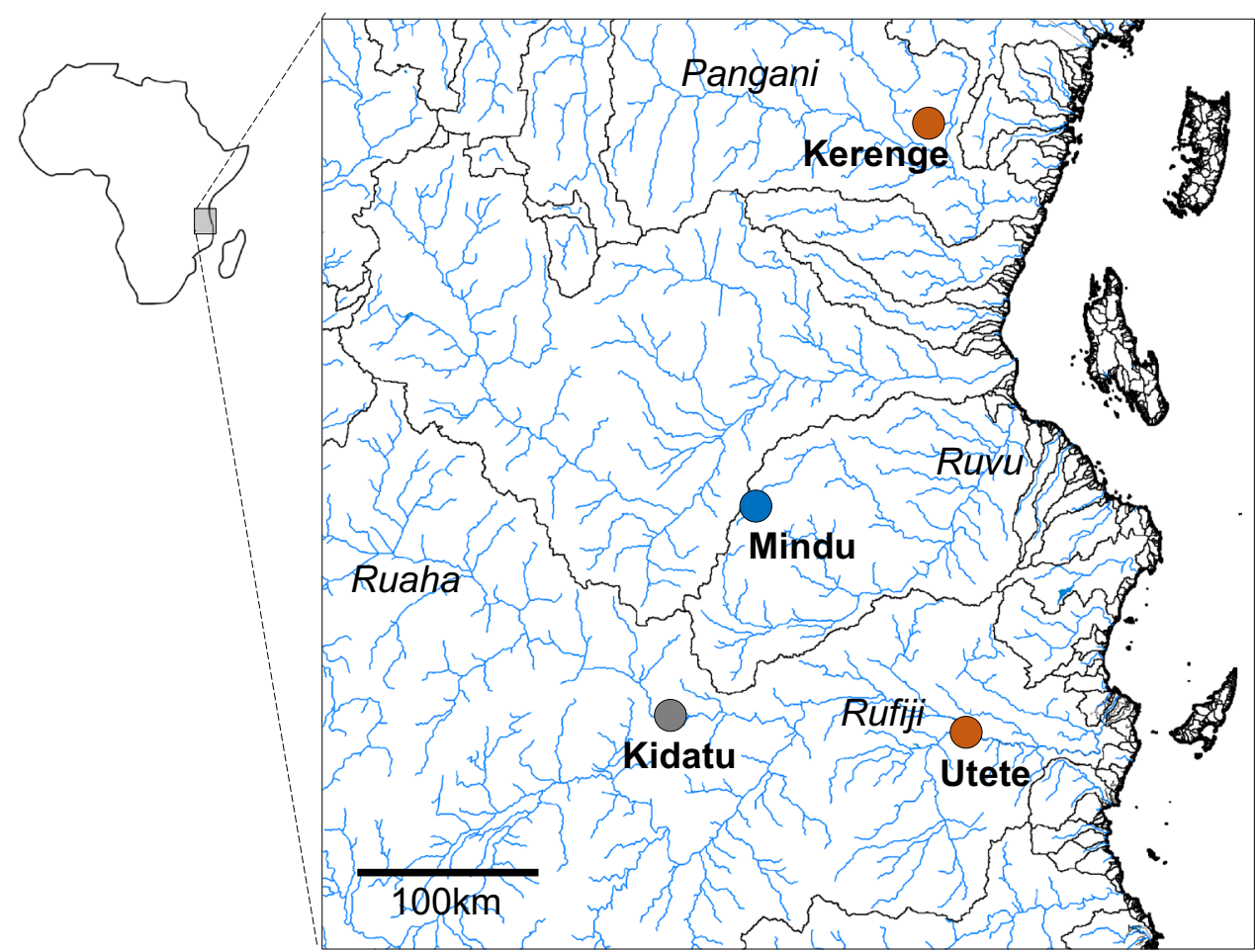


between $O$. urolepis and the introduced species were present. This was notable as there are no previous field-based records of hybridization between $O$. urolepis and either $O$. niloticus or O. leucostictus.

Here, we analyze specimens across the morphological range of individuals present in these systems to provide the first genetic tests of hybridization between these species in the wild, and to test if hybrids can be reliably distinguished on morphological characters alone. For the morphological work we chose to focus on (i) a combination of traditional linear morphological measurements of the head and body that are in principle readily measurable by fisheries researchers in the field, (ii) lower pharyngeal jaw (LPJ) measurements that can be indicative of dietary niche partitioning (e.g. Muschick et al. 2012), and (iii) geometric morphometric measurements of the head and body, that that can be powerful for discriminating cichlid species (e.g. Maderbacher et al. 2008).

\section{Methods}

\section{Study sites}

The study focussed on the two locations in Eastern Tanzania, the Mindu reservoir and the Kidatu reservoir. The Mindu reservoir is on the Ngerengere River, part of the Ruvu system, and construction of the dam began in 1983 and was completed in 1985 . The reservoir maintains a water supply for the Morogoro region, and has a maximum depth of $12 \mathrm{~m}$ and a surface area of $5.1 \mathrm{~km}^{2}$ (Kashaigili 2011). The Kidatu dam is across the Great Ruaha river, part of the larger Ruaha/ Rufiji/Kilombero system. Construction was completed in
1980, with a primary purpose in hydroelectric energy generation. The Kidatu reservoir has a maximum depth of $17 \mathrm{~m}$ and a surface area of $9.5 \mathrm{~km}^{2}$ (Yawson et al. 2006). At the time of sampling, both reservoirs supported small-scale artisanal fisheries activity.

\section{Sample collection and processing}

Samples from the focal sites (Mindu and Kidatu) were purchased at the point of landing from artisanal fishers operating with gill nets. At both sites, we selected samples to cover the range of morphological variation and colour patterning present. At Kidatu, fish were sampled from both the reservoir behind the main dam, and from river beneath the dam (Table 1). The sampling sites at Kidatu were separated by approximately $12 \mathrm{~km}$ of river.

Samples from the reference species $O$. niloticus and $O$. leucostictus were collected from seine nets from Kerenge on the Pangani river, and thus allopatric to the indigenous O. urolepis (Table 1). The two species could be separated in the field on the basis of body shape and colour patterning, and at this site no hybridization between $O$. niloticus and O. leucostictus has been observed (Bradbeer et al. 2018). Reference (pure) samples of $O$. urolepis were collected from artisanal fishers at Lugongwe near Utete on the lower Rufiji river (Table 1). This site was chosen as no specimens of $O$. niloticus or $O$. leucostictus have been collected in the vicinity during three sampling trips (August 2013; March 2015; April 2016), and therefore the population was inferred to comprise only purebred $O$. urolepis.

Individual fish were euthanised by anaesthetic overdose (MS-222 or clove oil), labelled and fin clips were taken and preserved in absolute ethanol for later genetic analysis. Fish

Table 1 Collection details and sample sizes for the genetic and morphometric analyses

\begin{tabular}{|c|c|c|c|c|c|c|}
\hline \multirow{2}{*}{$\begin{array}{l}\text { Samples } \\
\text { Location }\end{array}$} & \multicolumn{3}{|l|}{ Focal sites } & \multirow{2}{*}{$\begin{array}{l}\text { Reference } \\
\text { O. leucostictus } \\
\text { Pangani river }\end{array}$} & \multirow{2}{*}{$\begin{array}{l}\text { Reference } \\
\text { O. niloticus } \\
\text { Pangani river }\end{array}$} & \multirow{2}{*}{$\begin{array}{l}\text { Reference } \\
\text { O. urolepis } \\
\text { Utete }\end{array}$} \\
\hline & Mindu reservoir & Kidatu reservoir & Kidatu river & & & \\
\hline Latitude & $6.520^{\circ} \mathrm{S}$ & $7.634^{\circ} \mathrm{S}$ & $7.661^{\circ} \mathrm{S}$ & $5.032^{\circ} \mathrm{S}$ & $5.032^{\circ} \mathrm{S}$ & $7.590^{\circ} \mathrm{S}$ \\
\hline Longitude & $37.360^{\circ} \mathrm{E}$ & $36.885^{\circ} \mathrm{E}$ & $36.972^{\circ} \mathrm{E}$ & $38.548^{\circ} \mathrm{S}$ & $38.548^{\circ} \mathrm{S}$ & $38.450^{\circ} \mathrm{E}$ \\
\hline Sampling dates & $\begin{array}{l}11-1202 / 2015 \\
25 / 02 / 2015\end{array}$ & $\begin{array}{l}26 / 7 / 2015 \\
17-19 / 9 / 2015 \\
3 / 5 / 2016\end{array}$ & $3 / 5 / 2016$ & $12 / 08 / 2015$ & $12 / 08 / 2015$ & $\begin{array}{l}11 / 3 / 2015 \\
29 / 4 / 2015\end{array}$ \\
\hline $\mathrm{N}$ genetics & 158 & 94 & 25 & 9 & 30 & 49 \\
\hline $\mathrm{N}$ geometric morphometrics & 148 & 94 & 25 & - & - & - \\
\hline SL (mm) geometrics (mean; range) & $140(85-226)$ & $177(120-265)$ & $175(149-234)$ & - & - & - \\
\hline $\mathrm{N}$ body and head morphometrics & 156 & 80 & 16 & - & - & - \\
\hline SL (mm) body and head (mean; range) & $140(85-226)$ & $178(122-265)$ & $162(151-184)$ & - & - & - \\
\hline $\mathrm{N}$ pharyngeal jaw morphometrics & 118 & 72 & 11 & - & - & - \\
\hline SL (mm) pharyngeal jaw (mean; range) & $143(85-226)$ & $180(122-265)$ & $161(151-184)$ & & & \\
\hline
\end{tabular}

Reference material was only used for genetic analyses

SL standard length (mm) 
were then pinned out on an expanded polystyrene (Styrofoam) board and allowed to dry so that body shape and fin structure were partially fixed, facilitating subsequent measurements. The labelled specimens were then immersed in $100 \%$ ethanol, before transfer to $70 \%$ ethanol for long-term storage.

\section{Microsatellite genotyping}

DNA was extracted from fin tissue using the Wizard DNA extraction kit (Promega). Samples were initially screened at 18 microsatellite loci, sourced from Saju et al. (2010) and Liu et al. (2013) (Supplementary Information Table S1). PCR was performed in a volume of $10 \mu \mathrm{l}$ consisting of $1 \mu \mathrm{l}$ DNA ( $5 \mu$ l extracted DNA: $45 \mu$ l purite water), $5 \mu$ l Qiagen Multiplex 2x Mastermix and $4 \mu \mathrm{l}$ primer mix $(10 \mathrm{mM})$. Each primer was labelled with one dye from the DS-33 set (either 6-FAM, VIC, PET, NED). Loci were amplified within one of two multiplex PCR amplifications, each of which included one denaturation step of $15 \mathrm{~min}$ at $95{ }^{\circ} \mathrm{C}$, followed by 35 cycles of $30 \mathrm{~s}$ at $94{ }^{\circ} \mathrm{C}, 90 \mathrm{~s}$ at $57^{\circ} \mathrm{C}$ and $1 \mathrm{~min}$ at $72{ }^{\circ} \mathrm{C}$, followed by a final extension step of $30 \mathrm{~min}$ at $60{ }^{\circ} \mathrm{C}$. PCR products were then run on an $\mathrm{ABI} 3500$ capillary sequencer with the LIZ 500 size standard, before being scored using GeneMapper 4.1 (Applied Biosystems, MA).

\section{Microsatellite data analysis}

Estimation of genetic diversity, and associated tests of deviation from Hardy Weinberg Equilibrium, were made using default settings in Arlequin 3.5 (Excoffier and Lischer 2010). All individuals analyzed were screened using at least 13 of the 18 microsatellite loci. Two of the loci did not amplify successfully in all three species (Supplementary Information Table S2), and subsequent analyses were based on a core set of the remaining 16 loci that did amplify in all species (Supplementary Information Table S2). Genetic distances among specimens from both focal sites (Mindu and Kidatu) and reference samples, were ordinated using Factorial Correspondence Analysis in GENETIX 4.05 (Belkhir et al. 1999). Estimation of the genetic composition of individuals from the focal sites was achieved by first assigning individuals from both sites to one of three groups $(K=3)$ using the find. cluster function in the $\mathrm{R}$ package adegenet (Jombart and Ahmed 2011), selecting $K=3$, and employing all principal components. This resulting classification was then used as a prior in Structure (Pritchard et al. 2000), using 10 runs. Each run was for 200,000 iterations, with the first 100,000 iterations discarded as burn-in. The output was then summarized in Clumpak (Kopelman et al. 2015). To illustrate the genetic composition of samples collected at the focal sites, excluding reference individuals, we again used Factorial
Correspondence Analysis in GENETIX 4.05 (Belkhir et al. 1999).

To determine if our set of 16 loci were able to reliably identify hybrids, we simulated F1, F2 and backcross hybrids using HybridLab (Neilsen et al. 2006). We combined our purebred reference samples in a file with these simulated hybrids (100 individuals per hybrid category), and subjected them to the analysis procedure as described above using adegenet (Jombart and Ahmed 2011), and Structure (Pritchard et al. 2000).

\section{Geometric morphometrics}

In the laboratory, the left-hand side of each preserved specimen was photographed with a scale bar. Images were loaded into tpsDIG 2.26 (Rohlf 2005) and landmarked with 25 landmarks (Supplemental Information Fig. S1), following Genner et al. (2007). At this point individuals with $<80 \%$ likelihood of assignment to one group from the Structure analysis were identified as potential hybrids and individuals with $>80 \%$ likelihood as potential purebreds. We then used MorphoJ 1.06 (Klingenberg 2011) to conduct a Procrustes Analysis on all individuals combining both sampling locations. The resultant Procrustes coordinates were then regressed against standard length, and the resultant size-standardised Procrustes residuals were used in a single Canonical Variate Analysis to visualize shape variation among groups. Discriminant Function Analysis (DFA) in SPSS v23 (Armonk, NY: IBM Corporation) was used to test for morphological differences among groups. We entered the Procrustes residuals as DFA predictor variables simultaneously, and assigned individuals to one of three "known" groups (potential purebreds), or an "unknown" group (all potential hybrids regardless of parental species). Discriminant Function axis scores for each individual were calculated for all individuals, including hybrids.

\section{Traditional measurements}

We made 17 linear measurements of external morphology: standard length, body depth, head length, head width, inter-orbital eye width, snout length, lower jaw length, cheek depth, eye diameter, dorsal fin base length, anal fin base length, predorsal distance, preanal distance, prepelvic distance, preventral distance, caudal peduncle length and caudal peduncle depth. Additionally, we took four measurements from the lower pharyngeal jaw from calibrated images using tpsDIG 2.26 (Rohlf 2005): lower pharyngeal jaw length, lower pharyngeal jaw width, dentigerous area length and dentigerous area width. All measurements followed Snoeks (2004).

For each analysis of continuous data, measurements were $\log _{10}$ transformed, and isometrically size-standardized 
residuals were calculated for each variable using linear regression of each focal variable on standard length. Again samples from both sampling sites were pooled into the same analysis. Each set of size standardized residuals was entered into a Discriminant Function Analysis in SPSS v23, again entering the DFA predictor variables simultaneously, and assigning individuals to one of three "known" groups (potential purebreds), or an "unknown" group (potential hybrids). Discriminant Function axis scores for each individual were then calculated.

\section{Results}

\section{Molecular identification of hybrids}

Analysis of microsatellite allele frequencies indicated that our (purebred) reference material were assigned with greater than $80 \%$ probability, and so we used this as a threshold for the identification of purebred specimens from areas where hybridisation was suspected (Fig. 2; Supplementary Information Table S3). Our tests of simulated hybrids indicated that all F1 and F2 hybrids were correctly identified as hybrids using this $80 \%$ threshold, as were most (>75\%) backcross individuals (Supplementary Information Table S3).

In this way, we estimated that our 158 genotyped individuals from the Mindu reservoir comprised 26 purebred $O$. leucostictus, 18 purebred $O$. niloticus, 56 purebred $O$. urolepis, and 58 individuals of hybrid ancestry. Of these admixed individuals, most were hybrids between non-native species and the native $O$. urolepis (Fig. 3). There were no clear-cut 1st generation hybrids between $O$. niloticus and $O$. leucostictus. At Kidatu, the 119 individuals genotyped were estimated to comprise 90 purebred $O$. niloticus, 23 purebred $O$. urolepis, and 6 hybrids. One individual from Kidatu was identified as possessing substantial (42.4\%) O. leucostictus ancestry (possibly a 3-species hybrid: Fig. 2), while all others were largely $O$. urolepis $\times O$. niloticus. At Kidatu there was spatial variation in the distributions of purebreds and hybrids. Individuals from the Kidatu reservoir were primarily purebred $O$. niloticus or $O$. niloticus $\times$ urolepis hybrids, while those downstream of the dam in river were primarily $O$. urolepis, with some $O$. niloticus $\mathrm{x}$ urolepis hybrids present (Fig. 4).

\section{Geometric morphometric analyses}

Canonical variate analysis of geometric morphometric data based on individuals from the two admixture sites demonstrated substantial differences between the three species. Major axes of variation related to body depth and head shape. Canonical Variate axis 1 separated $O$. urolepis from $O$. niloticus, with $O$. urolepis possessing a longer snout and marginally reduced body depth relative to $O$. niloticus. Canonical Variate axis 2 separated $O$. urolepis and $O$. niloticus from $O$. leucostictus, with $O$. urolepis and $O$. niloticus having smaller eyes and greater body depths than O. leucostictus (Fig. 5). Discriminant function (DF) analysis revealed it was possible to significantly discriminate among populations on the first two axes (DF axis 1, Wilk's $\lambda=0.101, \chi^{2}=417.658, \mathrm{df}=90, P<0.001$; DF Axis 2 , Wilk's $\lambda=0.502, \chi^{2}=125.386, \mathrm{df}=44, P<0.001$ ). The method was reliably able to separate and categorize purebred
Fig. 2 Results of Structure assignment to species groups $(\mathrm{K}=3)$. Each row represents one individual fish. Individuals with $>0.80$ probability of assignment of to a species group $(80 \%)$ were assumed to be purebreds for subsequent analyses

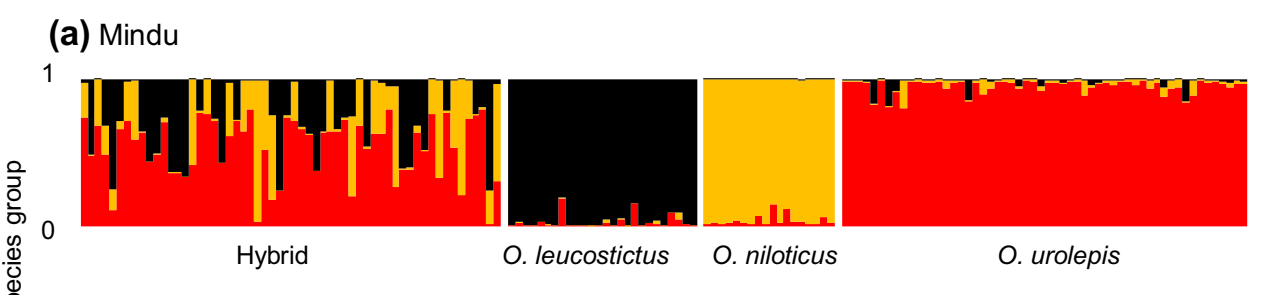

(b) Kidatu

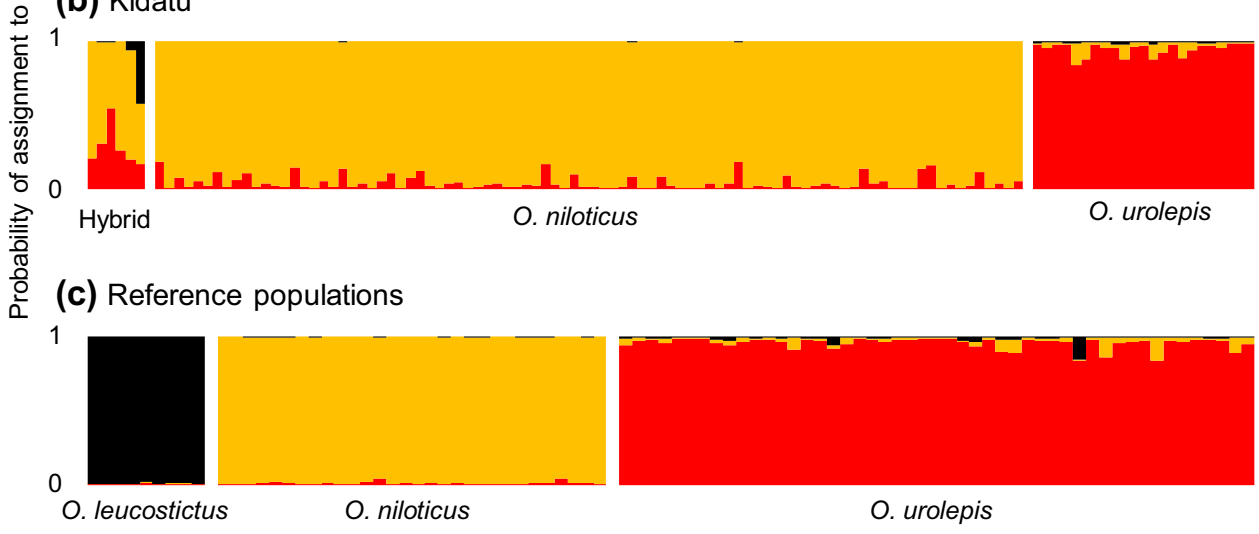


(a) Mindu and Kidatu, with references
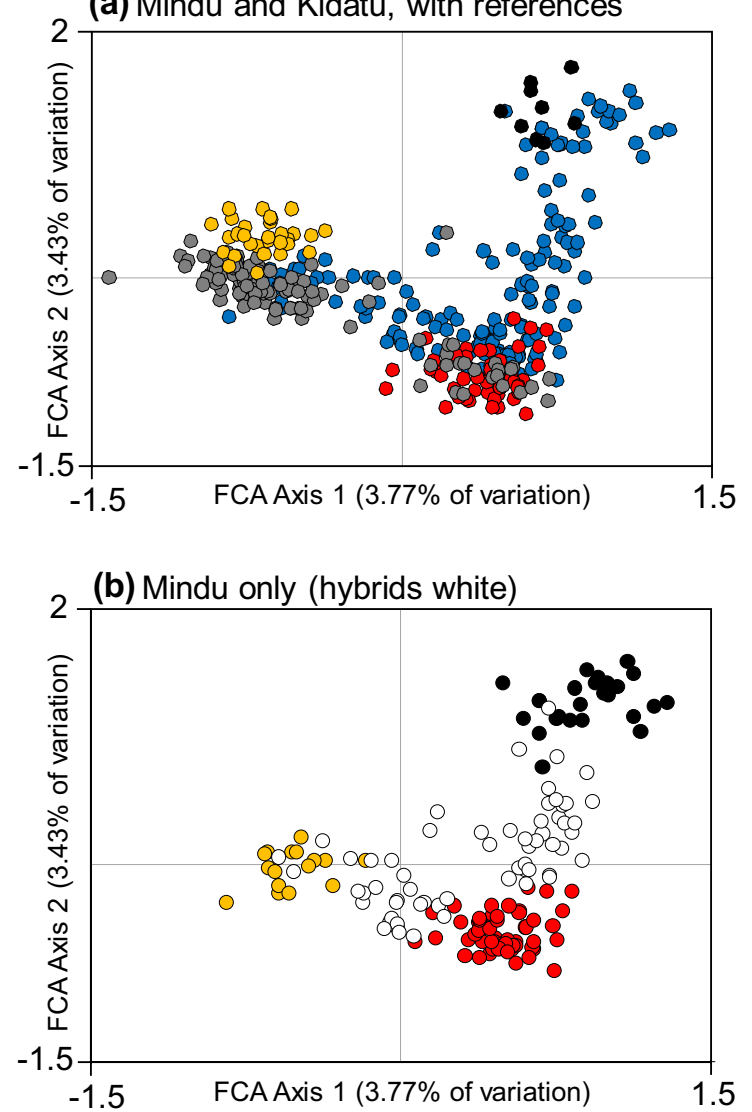

Fig. 3 Factorial Correspondence Analysis (FCA) plots illustrating genetic similarity of sampled individuals. In a the FCA includes individuals from the Mindu Dam (blue) and Kidatu (grey), in relation to reference samples of $O$. urolepis (red), O. niloticus (yellow) and O. leucostictus (black). In $\mathbf{b}$ and $\mathbf{c}$ FCA plots from one analysis are

individuals, with $92.3 \%$ of individuals correctly classified (Fig. 6; Table 2). Discriminant function scores demonstrated that individuals of hybrid ancestry at both sites encompassed a broad geometric morphospace, with some individuals similar to parental species, and others intermediate (Fig. 6).

\section{Traditional morphological analyses}

Traditional morphometric analysis could also discriminate among populations on the first axis (DF Axis 1, Wilk's $\lambda=0.653, \chi^{2}=76.432$, d.f. $\left.=32, P<0.001\right)$, but not the second (DF Axis 2; Wilk's $\lambda=0.919, \chi^{2}=15.194$, d.f. $=15$, $P=0.438)$. The strongest correlates of variation along DF Axis 1 (Table 3), were indicative of $O$. urolepis having relatively longer snouts and longer heads relative to $O$. niloticus and O. leucostictus (Table 3; Fig. 6). The method was able to reliably classify only $63.2 \%$ of purebred individuals (Table 2), with hybrid individuals overlapping substantially with purebreds (Fig. 6).

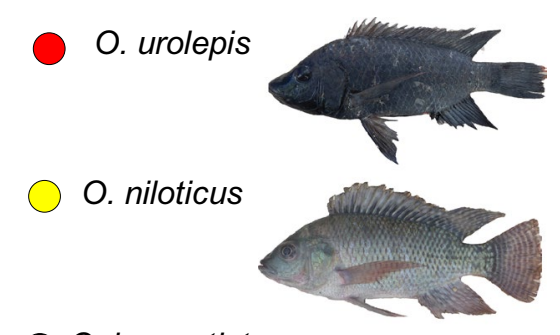

O. leucostictus

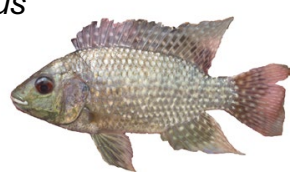

(c) Kidatu only (hybrids white)

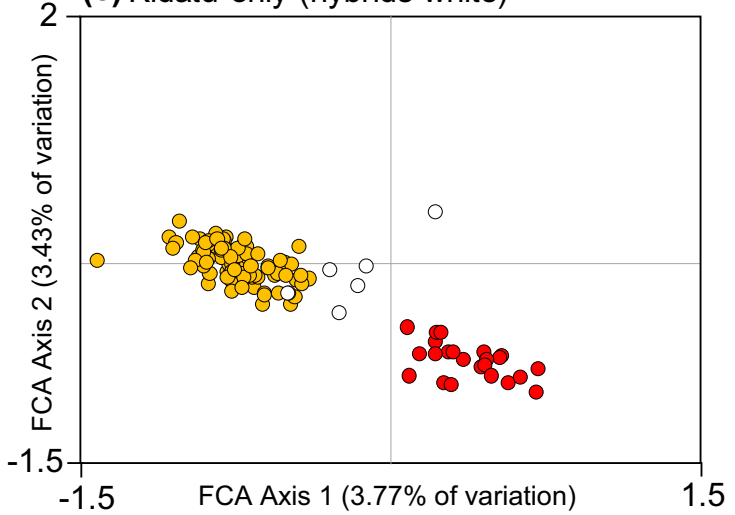

presented for the Mindu and Kidatu sites respectively, with individuals assigned as putative purebreds ( $>80 \%$ Structure assignment) as colored circles, and putative hybrids ( $<80 \%$ Structure assignment) as white circles. (Color figure online)

Discriminant function analysis of the lower pharyngeal jaw measurement data discriminated among populations on both of the first two major axes (DF Axis 1, Wilk's $\lambda=0.553$, $\chi^{2}=88.538$, d.f. $=8, P<0.001 ;$ DF Axis 2 , Wilk's $\lambda=0.853$, $\chi^{2}=23.810$, d.f. $=3, \mathrm{P}<0.001$ ). DF Axis 1 was indicative of $O$. urolepis having on average the longest and widest jaw of the three species, $O$. leucostictus having the shortest and narrowest jaw of the three species, with $O$. niloticus intermediate (Table 3; Fig. 6). Again, this analysis was a weaker discriminator that the geometric morphometric analysis of body shape, being able to classify only $64.3 \%$ of purebred individuals (Table 2), while hybrid individuals occupied most of the morphospace of the purebred fish (Fig. 6).

\section{Discussion}

Our molecular analyses supported our field observations that Oreochromis communities in the Kidatu and Mindu systems were comprised of multiple species, with reduced 


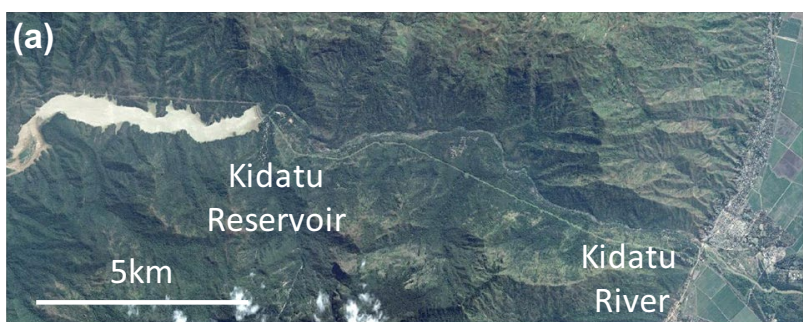

(b)

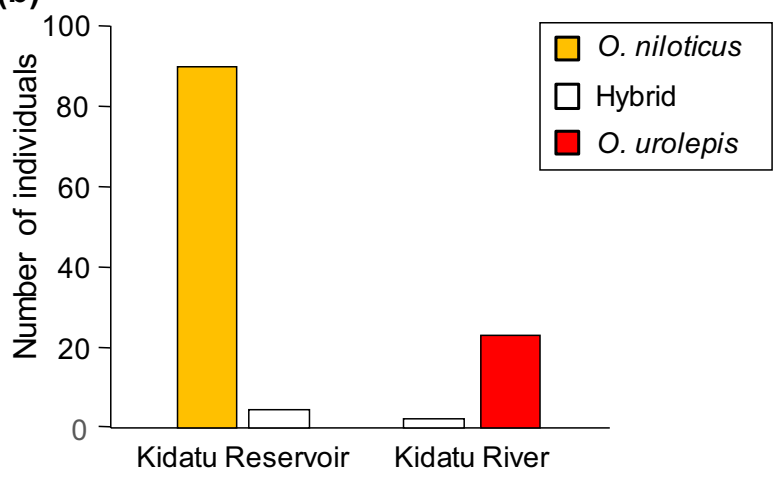

Fig. 4 a Satellite imagery of the Kidatu region. Image data CNES/ Airbus 13/7/2016 via Google Earth. b Number of individuals in the upstream reservoir and downstream river habitats sampled at Kidatu assigned to the purebred and hybrid genetic groupings

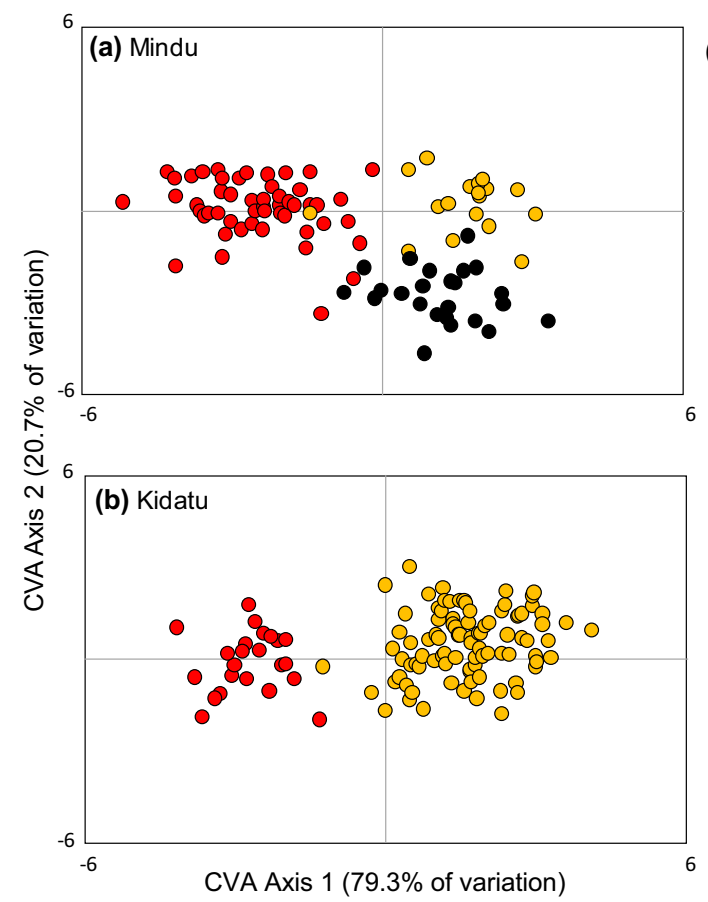

Fig. 5 Canonical variate analysis illustrating differences in geometric morphology among individuals classified as purebred in samples from a Mindu and b Kidatu. Colours indicate O. urolepis (red), $O$. niloticus (yellow) and $O$. leucostictus (black). c and $\mathbf{d}$ Variation along levels of heterozygosity across most loci consistent with the presence of genetic structure within populations (Supplementary Information Table S2). Further analyses were consistent with the presence of hybrids between the indigenous $O$. urolepis and the introduced $O$. niloticus and $O$. leucostictus. Evidence of hybridization between $O$. niloticus and $O$. urolepis has previously been demonstrated in aquaculture (Mapenzi and Mmochi 2016; Mbiru et al. 2016), but to our knowledge this the first evidence outside of captivity, and there are no previous reports of hybridization between $O$. urolepis and $O$. leucostictus.

Intriguingly, although we found $O$. niloticus $\times$ urolepis and $O$. leucostictus $\times$ urolepis hybrids to be commonplace in the Mindu reservoir, $O$. niloticus $\times$ leucostictus hybrids were less commonplace: indeed there was no clear-cut evidence of 1st generation hybrids between them. Oreochromis niloticus and O. leucostictus co-occur in Lakes Edward, George and Albert (Trewavas 1983), and thus it is plausible they are more strongly reproductively isolated than species pairs that are naturally allopatric in their distributions. Likewise, there is no evidence of admixture between these species at other locations in Tanzania that have been studied, including Lake Malimbe in the Victoria catchment, and Kerenge in the Pangani river system (Bradbeer et al. 2018). However, low levels of hybridization between $O$. niloticus and $O$. leucostictus have been reported in Kenya, but these involve

(c) Variation along CVA axis 1

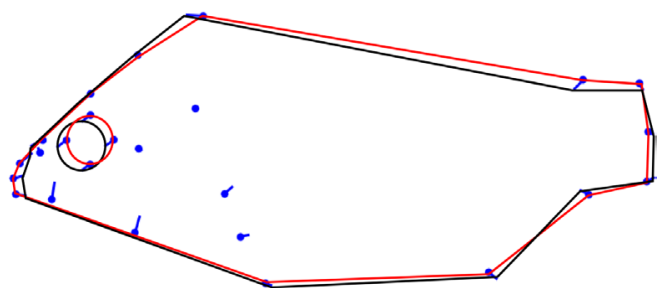

(d) Variation along CVA axis 2

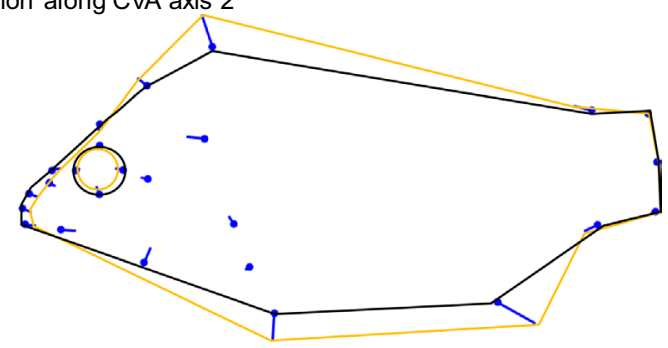

axes in head and body shape, with coloured lines representing those species at the extremes of the distributions. Samples from both sites were pooled into the same analysis, but locations are shown separately. (Color figure online) 

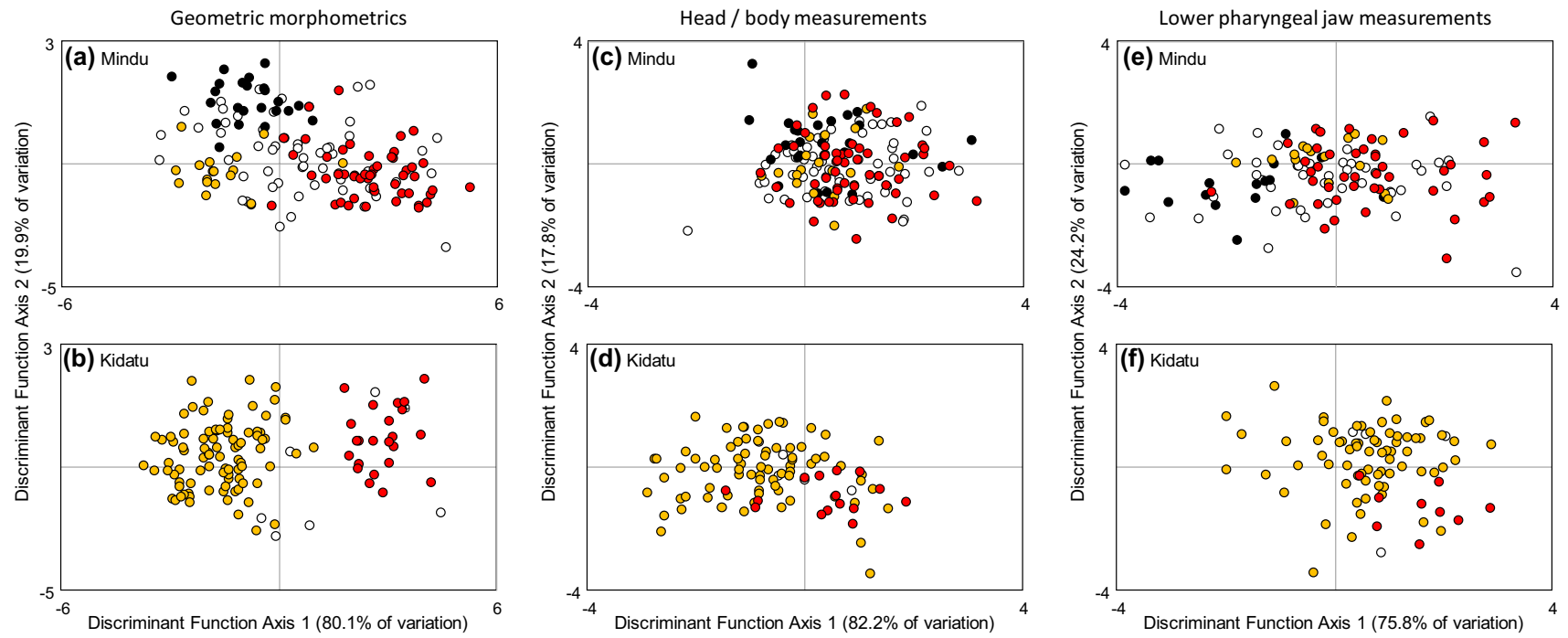

Fig. 6 Results of Discriminant Function Analyses of a, b geometric morphometric and $\mathbf{c}-\mathbf{f}$ traditional linear measurement data, with putatively purebred individuals ( $>80 \%$ assignment to a species group), and putative hybrid individual ( $<80 \%$ assignment to a species group).

Table 2 Discriminant function classification results, combined across the two sampling sites

\begin{tabular}{llll}
\hline Genetic grouping & \multicolumn{2}{l}{ Predicted grouping from morphology } & Total \\
\cline { 2 - 3 } & O. urolepis & O. niloticus & O. leucostictus
\end{tabular}

Geometric morphometrics

$\begin{array}{lllll}\text { O. urolepis } & 69(92.0 \%) & 2(2.7 \%) & 4(5.3 \%) & 75 \\ \text { O. niloticus } & 2(1.9 \%) & 99(91.7 \%) & 7(6.5 \%) & 108 \\ \text { O. leucostictus } & 0(0 \%) & 1(4.2 \%) & 23(95.8 \%) & 24 \\ \text { Hybrid } & 27(45.0 \%) & 17(28.3 \%) & 16(26.7 \%) & 60\end{array}$

Head/body measurements

$\begin{array}{lllll}\text { O. urolepis } & 44(63.8 \%) & 8(11.6 \%) & 17(24.6 \%) & 69 \\ \text { O. niloticus } & 16(16.8 \%) & 60(63.2 \%) & 19(20.0 \%) & 95 \\ \text { O. leucostictus } & 6(23.1 \%) & 4(15.4 \%) & 16(61.5 \%) & 26 \\ \text { Hybrid } & 28(45.2 \%) & 17(27.4 \%) & 17(27.4 \%) & 62\end{array}$

LPJ measurements

$\begin{array}{lllll}\text { O. urolepis } & 33(62.3 \%) & 18(34.0 \%) & 2(3.8 \%) & 53 \\ \text { O. niloticus } & 22(25.9 \%) & 53(62.4 \%) & 10(11.8 \%) & 85 \\ \text { O. leucostictus } & 1(6.3 \%) & 2(12.5 \%) & 13(81.3 \%) & 16 \\ \text { Hybrid } & 18(38.3 \%) & 15(31.9 \%) & 14(29.8 \%) & 47\end{array}$

the unique endemic subspecies $O$. niloticus baringoensis and specialized hot spring populations (Nyingi and Agnèse 2007; Ndiwa et al. 2014) likely to be genetically divergent from the Lake Albert/Nilotic populations of O. niloticus eduardiensis stocked in Lake Victoria and subsequently transferred around Tanzania.

To our knowledge this is the first evidence for substantive hybridization among introduced and indigenous Oreochromis in Tanzania. However, O. niloticus has been
Colors indicate $O$. urolepis (red), O. niloticus (yellow), O. leucostictus (black) and hybrid (white). Samples from both sites were pooled into the same analysis, but locations are shown separately. (Color figure online)

Table 3 Correlations of morphometric variables with Discriminant Function Anaysis (DFA) axes

\begin{tabular}{|c|c|c|c|}
\hline Trait category & Trait & DFA1 & DFA2 \\
\hline \multirow[t]{16}{*}{ Head and body } & Anal fin base & 0.339 & 0.076 \\
\hline & Body depth & 0.082 & -0.500 \\
\hline & Cheek depth & 0.398 & 0.316 \\
\hline & Caudal peduncle depth & 0.169 & -0.006 \\
\hline & Caudal peduncle length & 0.187 & -0.323 \\
\hline & Dorsal fin base length & -0.170 & 0.168 \\
\hline & Eye depth & 0.516 & -0.385 \\
\hline & Head length & 0.632 & -0.027 \\
\hline & Head width & 0.351 & -0.32 \\
\hline & Inter-orbital eye width & 0.280 & 0.201 \\
\hline & Lower jaw length & 0.194 & 0.204 \\
\hline & Preanal distance & -0.190 & 0.039 \\
\hline & Predorsal distance & 0.340 & -0.137 \\
\hline & Prepectoral distance & 0.188 & 0.048 \\
\hline & Prepelvic distance & 0.084 & -0.220 \\
\hline & Snout length & 0.772 & 0.170 \\
\hline \multirow[t]{4}{*}{ Lower pharyngeal jaw } & Dentigerous area length & 0.600 & 0.775 \\
\hline & Dentigerous area width & 0.947 & 0.037 \\
\hline & $\begin{array}{l}\text { Lower pharyngeal jaw } \\
\text { length }\end{array}$ & 0.551 & 0.274 \\
\hline & $\begin{array}{l}\text { Lower pharyngeal jaw } \\
\text { width }\end{array}$ & 0.738 & 0.219 \\
\hline
\end{tabular}

See Fig. 6 for the scores of individuals fish along these axes. Bold indicates the traits with the strongest associations with the DFA axes $(>0.6)$ 
reported to hybridize with indigenous species elsewhere in Africa, including with $O$. andersonii and $O$. macrochir in the Kafue river in Zambia (Deines et al. 2014). When hybrids are viable and fertile, continued introgression into both parental species can occur, generating a hybrid swarm, and threatening the integrity of the indigenous species through genetic swamping (Todesco et al. 2016). Our data suggest that hybrids are viable, and that the complex patterns in the Structure plots indicates that some of the hybrids are probably backcrosses, indicating a hybrid swarm. Follow up analyses with larger numbers of nuclear markers would be useful to identify these backcrossed hybrids more accurately, and the extent and direction of introgression among the species. At present it is not known if the hybrids have reduced fitness relative to purebreds in either of the systems, but this may account for the continued presence of apparently purebred individuals at both locations. Postzygotic selection against hybrid individuals has been shown to contribute to species integrity in other fish communities including sticklebacks (Vamosi and Schluter 1999; Gow et al. 2007) and cyprinids (Nilsson et al. 2017).

A key component of ecological selection against hybrids would be some evidence of niche differentiation among the purebreds. Further work is required to establish if such differences are present in our study systems. However, $O$. niloticus and $O$. leucostictus have been noted as having divergent habitat preferences in the native Lake Edward, with $O$. leucostictus being most abundant in peripheral habitats, while $O$. niloticus is primarily found in open waters (Trewavas 1983). Similar niche differentiation is reported for these species in Lake Victoria (Seehausen 1996). It is plausible that divergent habitat preferences may also explain the dominance of $O$. niloticus in the reservoir at Kidatu, in contrast to the dominance of $O$. urolepis in the river downstream of the dam, although this could also be explained by deliberate stocking of the reservoir with $O$. niloticus and relatively poor survival of fish passing through the dam.

\section{Hybrid identification}

Our field identification of purebred reference samples was based primarily on aspects of body colour, as all three species are distinguishable based on male breeding colors and patterning on the flanks and fins. Our study also demonstrated that purebred species were most readily separable using geometric morphometric characters, related to body depth and eye size, but linear measurements of head and body characters, and measurements of lower pharyngeal jaw morphology, also showed significance differences among the species. These results have relevance as they demonstrate that geometric characters can be used to assign individuals to species with reasonable confidence, and given close links between morphology and ecology in cichlids, then the species may differ in resource use patterns.

However, we discovered that hybrid individuals typically possessed a range of morphologies that were both overlapping with purebreds, and intermediate between them. We also found cases of hybrid individuals possessing morphologies that transgressed beyond those of the parental species. Such patterns are expected in cases where multiple hybrid generations are present, and novel combinations of alleles form (Seehausen 2004; Nichols et al. 2015). Since our results indicate that assignment of individuals based on morphology alone may lead to misassignment, we suggest that such classification should be coupled with evidence from genetic markers. It is also possible that colour patterning may be useful for hybrid identification, although this remains to be quantified, and may vary substantially between individuals depending on sex and reproductive state.

\section{Conservation}

Our analyses provide the first evidence of extensive hybridization between indigenous and invasive tilapiine cichlids in Tanzania, and illustrate the potential vulnerability of Tanzania's indigenous biodiversity to the threat posed by invasives. Here, the conservation of indigenous species faced by threats of hybridization with invasive species depends on the distribution of the invading species and the extent of hybridization. We have found $O$. niloticus and $O$. leucostictus to be distributed across multiple catchments in Tanzania, and to co-occur with $O$. urolepis in the Ruvu and Rufiji-Ruaha catchments as reported here, but we have also reported feral populations of $O$. niloticus and $O$. leucostictus in other locations where $O$. urolepis is indigenous. These include the Wami catchment (O. leucostictus and O. niloticus), the Mbwenkuru catchment (O. niloticus), as well as on Zanzibar (O. niloticus) (Shechonge et al. 2018). Further research is required to determine if hybrids are present in these systems, but the conservation of $O$. urolepis will likely depend on the identification and maintenance of habitats where $O$. leucostictus and $O$. niloticus are absent, and ideally these should be isolated from systems that harbour invasives. In North America, the concept of watershed-scale indigenous fish conservation areas is receiving increased attention (Williams et al. 2011), and the approach could be applied in Tanzania given there are still many smaller catchments, or parts of larger catchments, where invasive species have not been reported. For example, our genetic data support morphological observations suggesting an absence of invasives at Utete, and ox-bow lakes in the lower Rufiji region that contain only $O$. urolepis could be useful locations for conservation prioritization. Among other habitats in the region containing only the indigenous $O$. urolepis is Lake Mansi, an endorheic system between the Wami and Ruaha systems 
(Shechonge et al. 2018). Preservation of the biodiversity of these smaller catchments may benefit from formal recognition of their value for biodiversity conservation and potential for aquaculture future aquaculture.

\section{Concluding remarks}

In summary, our work adds to a growing body of evidence that introduction of non-native fish species can lead to hybridization with indigenous species and threaten unique biodiversity. Such introductions are typically associated with attempts at capture fisheries improvement, or the use of novel aquaculture species in circumstances where has been insufficient biocontrol to prevent them from unintentionally entering nearby water bodies. With increased demand for fish protein, governments will need to manage the potential ecological impacts of aquaculture and initiatives to enhance capture fisheries. It has been proposed that zoned aquaculture should be established, where the only species used are indigenous to the location (Lind et al. 2012). At present there is no evidence that $O$. niloticus can lead to greater yield than large-bodied indigenous species, and indeed if $O$. niloticus stocks are contaminated with small-bodied $O$. leucostictus then yields may even decline. It may be useful to adopt the precautionary principle of avoiding introduced species, unless there is compelling evidence for their ability to improve fisheries without biodiversity loss. Practically, the implementation of effective biosecurity measures will require training of fisheries extension officers on the impact of introducing non-native species to natural water bodies, as well as building capacity in species identification.

Acknowledgements The work was funded by Royal Society-Leverhulme Trust Africa Awards AA100023 and AA130107 to MJG, BPN and GFT, and BBSRC award BB/M026736/1 to GFT and MJG. We thank the Tanzania Commission for Research and Technology (COSTECH) for fieldwork permits, and staff of the Tanzania Fisheries Research Institute for contributions to fieldwork. We thank Einar Nielsen for providing HybridLab.

Data accessibility Genetic and morphometric data analysed for this manuscript have been deposited Dryad (https://doi.org/10.5061/dryad $.38 \mathrm{c} 4 \mathrm{~h} 63)$.

Open Access This article is distributed under the terms of the Creative Commons Attribution 4.0 International License (http://creativeco mmons.org/licenses/by/4.0/), which permits unrestricted use, distribution, and reproduction in any medium, provided you give appropriate credit to the original author(s) and the source, provide a link to the Creative Commons license, and indicate if changes were made.

\section{References}

Angienda PO, Lee HJ, Elmer KR, Abila R, Waindi EN, Meyer A (2011) Genetic structure and gene flow in an endangered native tilapia fish (Oreochromis esculentus) compared to invasive Nile tilapia (Oreochromis niloticus) in Yala swamp, East Africa. Conserv Genet 12:243-255

Belkhir K, Borsa P, Chikhi L, Raufaste N, Bonhomme F (1999) GENETIX, logiciel sous WindowsTM pour la génétique des populations. http://www.univmontp2.fr/ genetix

Bradbeer SJ, Harrington J, Watson H, Warraich A, Shechonge A, Smith A, Tamatamah R, Ngatunga BP, Turner GF, Genner MJ (2018) Limited hybridization between introduced and critically endangered indigenous tilapia fishes in northern Tanzania. Hydrobiologia. https://doi.org/10.1007/s10750-018-3572-5

D’Amato ME, Esterhuyse MM, Van Der Waal BC, Brink D, Volckaert FA (2007) Hybridization and phylogeography of the Mozambique tilapia Oreochromis mossambicus in southern Africa evidenced by mitochondrial and microsatellite DNA genotyping. Conserv Genet 8:475-488

Deines AM, Bbole I, Katongo C, Feder JL, Lodge DM (2014) Hybridisation between native Oreochromis species and introduced Nile tilapia $O$. niloticus in the Kafue River, Zambia. Afr J Aquat Sci 39:23-34

Deines AM, Wittmann ME, Deines JM, Lodge DM (2016) Tradeoffs among ecosystem services associated with global tilapia introductions. Rev Fish Sci Aquac 24:178-191

Eccles DH (1992) Field guide to the freshwater fishes of Tanzania. Species identification guide for fishery purposes. FAO, Rome

Eknath AE, Hulata G (2009) Use and exchange of genetic resources of Nile tilapia (Oreochromis niloticus). Rev Aquac 1:197-213

Excoffier L, Lischer HE (2010) Arlequin suite ver 3.5: a new series of programs to perform population genetics analyses under Linux and Windows. Mol Ecol Res 10:564-567

Facon B, Jarne P, Pointier JP, David P (2005) Hybridization and invasiveness in the freshwater snail Melanoides tuberculata: hybrid vigour is more important than increase in genetic variance. J Evol Biol 18:524-535

Gaskin JF, Schaal BA (2002) Hybrid Tamarix widespread in US invasion and undetected in native Asian range. Proc Natl Acad Sci USA 99:11256-11259

Genner MJ, Nichols P, Carvalho GR, Robinson RL, Shaw PW, Turner GF (2007) Reproductive isolation among deep-water cichlid fishes of Lake Malawi differing in monochromatic male breeding dress. Mol Ecol 16:651-662

Genner MJ, Connell E, Shechonge A, Smith A, Swanstrom J, Mzighani S, Mwijage A, Ngatunga BP, Turner GF (2013) Nile tilapia invades the Lake Malawi catchment. Afr J Aquat Sci 38(supp1):85-90

Goudswaard PC, Witte F, Katunzi EFB (2002) The tilapiine fish stock of Lake Victoria before and after the Nile perch upsurge. J Fish Biol 60:838-856

Gow JL, Peichel CL, Taylor EB (2007) Ecological selection against hybrids in natural populations of sympatric threespine sticklebacks. J Evol Biol 20:2173-2180

Jombart T, Ahmed I (2011) adegenet 1.3-1: new tools for the analysis of genome-wide SNP data. Bioinformatics 27:3070-3071

Kashaigili JJ (2011) Rapid environmental flow assessment for the Ruvu River. A consultancy report for iWASH. http://www.waterandna ture.org/sites/default/files/rapid_efa_for_ruvu_river_final_repor tkashaigili2011.pdf

Klingenberg CP (2011) MorphoJ: an integrated software package for geometric morphometrics. Mol Ecol Res 11:353-357

Kopelman NM, Mayzel J, Jakobsson M, Rosenberg NA, Mayrose I (2015) Clumpak: a program for identifying clustering modes and 
packaging population structure inferences across K. Mol Ecol Res 15:1179-1191

Lind CE, Brummett RE, Ponzoni RW (2012) Exploitation and conservation of fish genetic resources in Africa: issues and priorities for aquaculture development and research. Rev Aquac 4:125-141

Liu F, Sun F, Li J, Xia JH, Lin G, Tu RJ, Yue GH (2013) A microsatellite-based linkage map of salt tolerant tilapia (Oreochromis mossambicus x Oreochromis spp.) and mapping of sex-determining loci. BMC Genom 14:58

Lynch AJ, Cooke SJ, Deines AM, Bower SD, Bunnell DB, Cowx IG, Nguyen VM, Nohner J, Phouthavong K, Riley B, Rogers MW (2016) The social, economic, and environmental importance of inland fish and fisheries. Environ Rev 24:115-121

Maderbacher M, Bauer C, Herler J, Postl L, Makasa L, Sturmbauer C (2008) Assessment of traditional versus geometric morphometrics for discriminating populations of the Tropheus moorii species complex (Teleostei: Cichlidae), a Lake Tanganyika model for allopatric speciation. J Zool Syst Evol Res 46:153-161

Mapenzi LL, Mmochi AJ (2016) Effect of stocking density on growth performance of hybrids of Oreochromis niloticus 9 and Oreochromis urolepis urolepis $\widehat{\supset}$ in saline water. West Ind Ocean $\mathbf{J}$ Mar Sci 15:67-74

Mbiru M, Limbu SM, Chenyambuga SW, Lamtane HA, Tamatamah R, Madalla NA, Mwandya AW (2016) Comparative performance of mixed-sex and hormonal-sex-reversed Nile tilapia Oreochromis niloticus and hybrids (Oreochromis niloticus $\times$ Oreochromis urolepis hornorum) cultured in concrete tanks. Aquacult Int 24:557-566

McIntyre PB, Liermann CAR, Revenga C (2016) Linking freshwater fishery management to global food security and biodiversity conservation. Proc Natl Acad Sci USA 113:12880-12885

Mkumbo OC, Marshall BE (2015) The Nile perch fishery of Lake Victoria: current status and management challenges. Fish Manag Ecol 22:56-63

Muschick M, Indermaur A, Salzburger W (2012) Convergent evolution within an adaptive radiation of cichlid fishes. Curr Biol 22:2362-2368

Ndiwa TC, Nyingi DW, Agnèse JF (2014) An important natural genetic resource of Oreochromis niloticus (Linnaeus, 1758) threatened by aquaculture activities in Loboi drainage, Kenya. PLoS ONE 9:e106972

Nichols P, Genner MJ, Van Oosterhout C, Smith A, Parsons P, Sungani H, Swanstrom J, Joyce DA (2015) Secondary contact seeds phenotypic novelty in cichlid fishes. Proc R Soc Lond B 282:20142272

Nielsen EE, Bach LA, Kotlicki P (2006) HYBRIDLAB (version 1.0): a program for generating simulated hybrids from population samples. Mol Ecol Res 6:971-973

Nilsson PA, Hulthén K, Chapman BB, Hansson LA, Brodersen J, Baktoft H, Vinterstare J, Brönmark C, Skov C (2017) Species integrity enhanced by a predation cost to hybrids in the wild. Biol Lett 13:20170208

Nyingi DW, Agnèse JF (2007) Recent introgressive hybridization revealed by exclusive mtDNA transfer from Oreochromis leucostictus (Trewavas, 1933) to Oreochromis niloticus (Linnaeus, 1758) in Lake Baringo, Kenya. J Fish Biol 70:148-154

Olden JD, Poff NL, Douglas MR, Douglas ME, Fausch KD (2004) Ecological and evolutionary consequences of biotic homogenization. Trends Ecol Evol 19:18-24
Perry WL, Lodge DM, Feder JL (2002) Importance of hybridization between indigenous and nonindigenous freshwater species: an overlooked threat to North American biodiversity. Syst Biol $51: 255-275$

Pritchard JK, Stephens M, Donnelly P (2000) Inference of population structure using multilocus genotype data. Genetics 155:945-959

Rohlf FJ (2005) tpsDig, digitize landmarks and outlines, version 2.05. Department of Ecology and Evolution, State University of New York, Stony Brook

Saju JM, Lee WJ, Orban L (2010) Characterization of nine novel microsatellites isolated from Mozambique tilapia, Oreochromis mossambicus. Cons Genet Res 2:385-387

Scribner KT, Page KS, Bartron ML (2000) Hybridization in freshwater fishes: a review of case studies and cytonuclear methods of biological inference. Rev Fish Biol Fish 10:293-323

Seehausen O (1996) Lake victoria rock cichlids. Verduijn Cichlids, Germany

Seehausen O (2004) Hybridization and adaptive radiation. Trends Ecol Evol 19:198-207

Shechonge A, Ngatunga BP, Bradbeer SJ, Day JJ, Freer JJ, Ford AG, Kihedu J, Richmond T, Mzighani S, Smith AM, Sweke EA, Tamatamah R, Tyers AM, Turner GF, Genner MJ (2018) Widespread colonisation of Tanzanian catchments by introduced Oreochromis tilapia fishes: the legacy from decades of deliberate introduction. Hydrobiologia. https://doi.org/10.1007/s1075 $0-018-3597-9$

Snoeks J (2004) The cichlid diversity of Lake Malawi/Nyasa/Niassa: identification, distribution and taxonomy. Cichlid Press, El Paso

Todesco M, Pascual MA, Owens GL, Ostevik KL, Moyers BT, Hübner S, Heredia SM, Hahn MA, Caseys C, Bock DG, Rieseberg LH (2016) Hybridization and extinction. Evol Appl 9:892-908

Trewavas E (1983) Tilapiine fishes of the genera Sarotherodon, Oreochromis and Danakilia. British Museum (Natural History), London

Vamosi SM, Schluter D (1999) Sexual selection against hybrids between sympatric stickleback species: evidence from a field experiment. Evolution 53:874-879

Vörösmarty CJ, McIntyre PB, Gessner MO, Dudgeon D, Prusevich A, Green P, Glidden S, Bunn SE, Sullivan CA, Liermann CR, Davies PM (2010) Global threats to human water security and river biodiversity. Nature 467:555-561

Welcomme RL, Cowx IG, Coates D, Béné C, Funge-Smith S, Halls A, Lorenzen K (2010) Inland capture fisheries. Phil Trans R Soc Lond B 365:2881-2896

Williams JE, Williams RN, Thurow RF, Elwell L, Philipp DP, Harris FA, Kershner JL, Martinez PJ, Miller D, Reeves GH, Frissell CA (2011) Native fish conservation areas: a vision for large-scale conservation of native fish communities. Fisheries 36:267-277

Winemiller KO, McIntyre PB, Castello L, Fluet-Chouinard E, Giarrizzo T, Nam S, Baird IG, Darwall W, Lujan NK, Harrison I, Stiassny MLJ (2016) Balancing hydropower and biodiversity in the Amazon, Congo, and Mekong. Science 351:128-129

Yawson DK, Kongo VM, Kachroo RK (2006) Impact assessment of Mtera and Kidatu reservoirs on the annual maximum floods at Stiegler's Gorge of the Rufiji River in Tanzania. Water Int $31: 100-108$ 